\title{
HUBUNGAN KEBUTUHAN PENGHARGAAN (ESTEEM NEEDS) DAN KOIMPETISI DALAM BELAJAR (LEARNING OF COMPETITION) DENGAN KREATIVITAS BELAJAR FISIKA SISWA MTS MADANI ALAUDDIN PAO-PAO KABUPATEN GOWA
}

\author{
Muhammad Yusuf Hidayat \\ Fakultas Tarbiyah dan Keguruan UIN Alauddin Makassar
}

\begin{abstract}
Maslow in Poduska (2000: 201) defines the need for an esteem needs to be a person's desire for good judgment from others, to be respected and to receive praise from a teacher. Marcus Verrius Flaccus in Monks et al (1999: 279) argues that the learning competition is a learning activity, students competing for each other to get good learning outcomes. The existence of competition or student competition in the learning process (learning of competition) is one of the strong factors in motivating students in learning. Barro in Ali and Asrori (2006: 41) that creativity is the ability to create something new, something new does not mean to be entirely new, but can also be a combination of elements that have been there before. This study aims to describe and interpret the relationship of the need for awards (esteem needs) and competition in learning (learning of competition) with students' physics learning creativity MTs Madani Alauddin Pao-Pao Gowa District. The type of this research is descriptive correlational research. The population of this study is all students of MTs 2012/2013 school year. The sample using Proportional Stratified Random Sampling technique is by taking representative sample where the researcher takes $25 \%$ from the existing population that is 40 students from 160 students of MTs Madani Alauddin Pao-Pao Gowa District and with sampling based on grade level then taken at random. To obtain the data of researchers using questionnaires and interview guides conducted by researchers to physics teachers of each class. Data analysis techniques used are descriptive statistics and inferential statistics for hypothesis testing.
\end{abstract}

Keywords: Esteem needs, learning in competition, learning creativity.

\section{PENDAHULUAN}

$\mathrm{P}$ endidikan merupakan media yang sangat berperan untuk menciptakan manusia yang berkualitas yang berpotensi dalam arti yang seluas-luasnya, melalui pendidikan akan terjadi proses pendewasaan diri sendiri sehingga di dalam proses pengambilan keputusan terhadap suatu masalah yang dihadapi selalu disertai dengan rasa tanggung jawab yang besar. Dalam rangka meningkatkan mutu pendidikan di Indonesia, telah banyak usaha yang dilakukan pemerintah, beberapa diantaranya ialah melakukan perubahan kurikulum. Namun kenyataanya masih banyak belum mencapai 
hasil yang memuaskan. Untuk pencapaian tujuan tersebut, diharapkan tiap-tiap sekolah berusaha meningkatkan kualitas sehingga tujuan pendidikan dapat tercapai.

Untuk meningkatkan pendidikan tentu saja tidak terlepas dari guru dan proses belajar mengajar sebagai kegiatan utama di sekolah. Guru mempunyai dampak besar pada anak didik, bukan hanya menyangkut prestasi tetapi juga pada sikap anak terhadap sekolah dan belajar. Guru dapat melumpuhkan kemelitan (rasa ingin tahu) alamiah, merusak motivasi, harga diri dan kreativitas anak. Tetapi, guru juga dapat berperan sebaliknya yaitu mampu mendorong kemelitan (rasa ingin tahu) alamiah, memotivasi, harga diri dan kreativitas anak, bahkan guru yang sangat baik dapat mempengaruhi anak lebih kuat daripada orang tua.

Guru dapat mengembangkan kreativitas siswa lewat sikap dan penggunaan teknikteknik yang dapat digunakan untuk mengembangkan kreativitas siswa. Pada dasarnya guru tidak dapat mengajarkan kreativitas tetapi ia dapat memungkinkan kreativitas muncul, memupuknya dan merangsang pertumbuhannya. ${ }^{1}$

Pembelajaran di sekolah merupakan bagian dari fokus pendidikan yang bukan sekedar memiliki kemampuan kognitif saja, namun juga berfokus pada potensi keterampilan serta kreativitas yang dimiliki siswa untuk mewujudkan perubahan tingkah laku dengan mengembangkan potensi-potensi yang dimiliki agar menjadi insan yang beriman dan bertakwa kepada Allah SWT. Teknik-teknik mengajar yang digunakan oleh guru merupakan penentu dalam proses belajar siswa.

Apabila teknik yang digunakan tersebut sesuai dengan materi yang akan diajarkan, maka pembelajaran akan menjadi menarik dan dapat memotivasi siswa untuk membangkitkan minat terhadap pelajaran tersebut. Namun sebaliknya, apabila suatu teknik yang digunakan tersebut kurang sesuai dengan materi yang diajarkan, maka proses belajar mengajar tidak akan menarik dan membuat siswa bosan sehingga minat terhadap pelajaran tersebut menjadi rendah. Maka pendidik harus inovatif dalam pembelajarannya karena setiap materi membutuhkan teknik yang berbeda-beda supaya peserta didik tetap aktif dan kreatif dalam pembelajarn dan memahami setiap materi yang disajikan oleh guru. Kreativitas belajar siswa berkaitan dengan seberapa besar siswa memiliki keinginan yang kuat untuk terlibat secara aktif dalam proses belajar. Keinginan yang kuat serta keterlibatan aktif dalam proses belajar menunjukkan kadar atau kondisi motivasi belajar yang dimiliki siswa.

Kreativitas belajar siswa dapat dipengaruhi oleh berbagai faktor. Faktor-faktor yang mempengaruhi kreativitas belajar siswa menurut Munandar terdiri dari aspek kognitif dan aspek kepribadian. Akan tetapi faktor penting dalam meningkatkan kreativitas belajar siswa adalah peran guru. Beberapa faktor ini yang mempengaruhi kreativitas belajar berkaitan dengan keterampilan mengajar yang perlu dimiliki oleh seorang guru. 156.

${ }^{1}$ Utami Munandar, Pengembangan Kreativitas Anak Berbakat (Jakarta: Rineka Cipta, 2009), hlm. 
Kajian yang berkenaan dengan kreativitas belajar siswa sebagaimana dilakukan oleh Susilowati (2004) pada kelas akselerasi di SMP Islam Al-Azhar 1 Jakarta menemukan bahwa terdapat $68,2 \%$ yang berminat pada pelajaran IPA dan $25 \%$ pada pelajaran IPS. Dari $68,2 \%$ siswa yang berminat pada pelajaran IPA, faktor terbesar bukan berasal dari dalam diri siswa melainkan dari faktor pelajaran itu sendiri $(53,7 \%)$. Selain faktor pelajaran, terdapat faktor cara mengajar guru bidang studi (17\%), faktor guru yang tidak berkaitan dengan cara mengajar (12,2\%), faktor suasana kelas ketika kegiatan belajar mengajar $(4,9 \%)$, dan faktor lainnya $(12,2 \%)$. Selain itu, dari $25 \%$ siswa kelas akselerasi yang meminati pelajaran IPS diketahui bahwa motivasi siswa belajar adalah faktor pelajaran itu sendiri $(38,1 \%)$. Selebihnya, karena faktor guru $(33,3 \%)$, cara mengajar guru $(23,8 \%)$, suasana kelas $(4,8 \%)$, dan faktor lainnya $(0 \%)$ http://journal.unair.ac.id/filerPDF/artikel\%201-13-1.pdf (12 Oktober 2012).

Guru merupakan penggerak kegiatan belajar para siswanya. Ia harus menyusun suatu rencana tentang cara-cara melakukan tindakan serta mengumpulkan bahan-bahan yang dapat membangkitkan serta menolong para siswa agar mereka terus melakukan usaha-usaha yang efektif untuk mencapai tujuan-tujuan belajar. Sebagian dari siswa yang masuk sekolah dan memiliki tujuan-tujuan belajar dalam pikirannya, bagi mereka ini mungkin hanya diperlukan sedikit bantuan untuk membangkitkan motif-motifnya. Setiap guru berusaha memotivasi semua anak dengan teknik yang sama. Oleh karena itu, guru perlu terus belajar mengenai cara-cara membangkitkan motif. Suatu teori menyatakan bahwa pemberian motivasi yang berhasil harus berasal dari pemenuhan kebutuhan dasar para siswa.

Menurut Maslow, apabila kebutuhan-kebutuhan pada suatu tahap tertentu dapat dipenuhi, maka kebutuhan-kebutuhan berikutnya yang lebih tinggi akan menjadi sangat kuat. Adapun kebutuhan individu menurut teori Maslow adalah kebutuhan akan penghargaan (esteem needs). Kebutuhan akan penghargaan (esteem needs) ialah keinginan seseorang untuk penilaian yang baik dari orang lain serta ingin dihormati. Harga diri seseorang timbul dalam hubungannya dengan orang lain di dalam kelompoknya. Hal ini erat hubungannya dengan statusnya di dalam kelompok dan penghargaan orang lain terhadapnya. Seorang akan merasa dirinya dihargai oleh orang lain kalau ia merasa bahwa dirinya dianggap penting. Tentunya tugas seorang guru adalah menemukan sesuatu di dalam diri anak didik yang dapat dilakukannya, yaitu sesuatu yang dapat membuat anak didiknya merasa bahwa dirinya penting. ${ }^{2}$

Pada umumnya penghargaan mempunyai pengaruh positif dalam kehidupan manusia, dalam hal ini bagi siswa-siswi yang sedang melaksanakan proses pembelajaran. Dengan adanya penghargaan dari seorang guru maka akan mendorong siswa-siswi memperbaiki tingkah laku dan meningkatkan kreatifitas belajarnya.

2 Oemar Hamalik, Perencanaan Pengajaran Berdasarkan pendekatan Sistem (Bandung: Bumi Aksara, 2001), hlm. 176-177. 
Dalam kegiatan belajar mengajar, penghargaan mempunyai arti penting. Tingkah laku dan keberhasilan belajar siswa-siswi, diberi penghargaan dalam bentuk pujian, senyuman, dan sebagainya. Dengan adanya penghargaan dari guru, maka siswa akan terus belajar secara maksimal untuk mendapatkan penghargaan tersebut. Bahkan siswa tersebut akan bersaing atau melakukan kompetisi dengan siswa-siswa yang lain. Adanya persaingan atau kompetisi siswa dalam proses belajar merupakan salah satu faktor yang kuat dalam memotivasi siswa dalam belajar. Hal ini terkait dengan cara siswa membekali diri mereka dengan kemauan dan potensi yang dimiliki, sehingga menjadikan belajar sebagai acuan memperoleh prestasi.

Melalui kompetisi dalam belajar, maka siswa dengan sendirinya akan berusaha semaksimal mungkin memperoleh hasil yang baik dibanding dengan sebelumnya. Dalam praktknya, siswa sebagai pelajar cenderung membentuk kelompok belajar dan bermain dengan teman sebayanya, mereka menganggap bahwa teman sebayanya bukan saja sebagai teman bermain dan teman belajar, melainkan sebagai mereka dalam mencapai prestasi dikelas. Diharapkan dengan adanya motivasi belajar yang tinggi siswa dapat belajar dengan giat, mampu memperoleh prestasi yang baik dan menjadikan teman-teman sebagai sarana untuk menumbuhkan keinginan dan semangat dalam belajar.

Berdasarkan uraian di atas, maka penulis terinspirasi untuk melakukan penelitian dengan judul "Hubungan Kebutuhan Penghargaan (Esteem Needs) dan Kompetisi dalam Belajar (Learning of Competition) dengan Kreativitas Belajar Fisika Siswa MTs Madani Alauddin Pao-Pao Kabupaten Gowa”.

\section{METODE PENELITIAN}

Penelitian ini termaksuk penelitian deskriptif kuantitatif yang bertujuan untuk menggambarkan dan menginterpretasikan hubungan kebutuhan penghargaan (esteem needs) dan kompetisi dalam belajar (learning of competition) dengan kreativitas belajar fisika siswa MTs Madani Alauddin Pao-Pao Kabupaten Gowa.

Populasi adalah wilayah generalisasi yang terdiri atas objek/subjek yang mempunyai kualitas dan karakteristik tertentu yang ditetapkan oleh peneliti untuk dipelajari dan kemudian ditarik kesimpulannya. Jadi, populasi bukan hanya orang, tetapi juga objek dan benda-benda alam yang lain. Populsi juga bukan sekadar jumlah yang ada pada objek/subjek yang dipelajari, tetapi meliputi seluruh karakteristik/sifat yang dimiliki oleh subjek atau objek itu. ${ }^{3}$ Adapun jumlah populasi dalam penelitian ini adalah seluruh siswa MTs Madani Alauddin Pao-Pao Kabupaten Gowa dengan jumlah peserta didik sebanyak $160 .^{4}$ hlm. 117.

${ }^{3}$ Sugiyono, Metodologi Penelitian Kuantitatif, Kualitatif, dan R\& D (Bandung: Alfabeta, 2012),

${ }^{4}$ Sumber Data Sekolah Tahun ajaran 2012-2013. 
Dalam penelitian ini peneliti hanya mengambil sampel dari masing-masing kelas VII, VIII dan IX dari keseluruhannya, ini dilakukan karena peneliti ingin sebagian dari jumlah dan karakteristik yang dimiliki oleh populasi. Sampel adalah bagian dari jumlah dan karakteristik yang dimiliki oleh populasi tersebut. ${ }^{5}$ Apabila populasi besar dan peneliti tidak mungkin mempelajari semua yang ada pada populasi, maka dapat menggunakan sampel yang diambil dari populasi dengan menggunakan teknik Random Sampling. Pengambilan sampel yang dilakukan sedemikian rupa sehingga diperoleh sampel yang benar-benar dapat berfungsi sebagai contoh, atau dapat menggambarkan keadaan populasi yang sebenarnya.

Apabila subjeknya kurang dari 100, lebih baik dimbil semua sehingga pnelitiannya merupakan penelitian populasi, jika jumlah subjeknya besar dapat diambil antara $10-15 \%$ atau 20-25\% atau lebih. ${ }^{6}$ Berdasarkan data sekolah dengan jumlah 160 peserta didik. Dalam hal ini, peneliti mengambil 25\% dari jumlah populasi 160 dari $25 \%$ diperoleh 40 sampel yang diteliti.

Penelitian ini terdiri dari tiga variabel, yang terdiri dari dua variabel independen dan satu variabel dependen. Variabel independen berupa (1) kebutuhan penghargaan (2) kompetisi dalam belajar dan untuk variabel dependen adalah kreativitas belajar fisika. Untuk menjawab hipotesis dibutuhkan instrument penelitian, dalam hal ini menurut (Sudjana, 2009: 97), keberhasilan penelitian banyak ditentukan oleh instrumen yang digunakan, sebab data yang diperlukan untuk menjawab pertanyaan penelitian (masalah) dan menguji hipotesis diperoleh melalui instrumen. Instrumen sebagai alat pengumpul data harus betul-betul dirancang dan dibuat sedemikian rupa sehingga menghasilkan data empiris sebagaimana adanya. Dalam penelitian ini, ada beberapa instrumen penelitian yang digunakan yaitu: (1) Kuesioner adalah sederetan pertanyaan atau pernyataan tentang sikap seseorang terhadap keadaan diri dan ligkungannya.

Kuesioner terdiri atas dua yaitu kuesioner terbuka dan kuesioner tertutup. Berdasarkan uraian di atas, maka jenis kuesioner yang digunakan dalam penelitian ini adalah kuesioner tertutup dengan pertimbangan bahwa variabel yang akan diteliti dalam penelitian ini menyangkut pribadi dan kejiwaan seseorang dengan menggunakan skala likert maka variabel yang akan diukur dijabarkan menjadi indikator variabel. Kemudian indikator tersebut dijadikan sebagai titik tolak untuk menyusun item-item instrumen yang dapat berupa pertanyaan atau pernyataan. Kuesioner atau angket yang digunakan dalam penelitian ini berbentuk pernyataan dengan jumlah item masing-masing, untuk kebutuhan penghargaan (esteem needs) berjumlah 23 item yang terdiri dari 18 item positif dan 5 item negatif. Pada kompetisi dalam belajar (learning of competition) berjumlah 20 item dengan 14 item positif dan 6 item negatif. Sementara pada kreativitas

\footnotetext{
hlm. 81 .

${ }^{5}$ Sugiyono, Metodologi Penelitian Kuantitatif, Kualitatif, dan R\& D (Bandung: Alfabeta, 2009),

${ }^{6}$ Arikunto, Suharsimi. Manejemen Penelitian (Jakarta: Rineka Cipta, 2010), hlm. 109-112.
} 
belajar fisika jumlah item yang digunakan yaitu 30 dengan jumlah item positif 22 dan item negatif 8 item.

Jawaban setiap item instrumen yang menggunakan skala likert mempunyai gradasi dari sangat sesuai, sesuai, kurang sesuai, dan tidak sesuai. ${ }^{7}$ (2) Wawancara adalah pertemuan dua orang untuk bertukar informasi dan ide melalui tanya jawab sehingga dapat dikonstruksikan makna dalam suatu topik tertentu. Wawancara digunakan sebagai tekhnik pengumpulan data apabila peneliti ingin melakukan studi pendahuluan untuk menemukan permasalahan yang harus diteliti, tetapi juga apabila peneliti ingin mengetahui hal-hal dari responden yang lebih mendalam. Tekhnik pengumpulan data ini mendasarkan diri pada laporan tentang diri sendiri atau selfreport, atau setidak-tidaknya pada pengetahuan dan atau keyakinan pribadi. ${ }^{8}$

Jenis wawancara yang digunakan dalam penelitian ini adalah wawancara tidak terstruktur. Menurut Sugiyono, ${ }^{9}$ wawancara tidak terstruktur adalah wawancara yang bebas di mana peneliti tidak mengguanakan pedoman wawancara yang telah tersususn secara sistematis dan lengkap untuk pengumpulan datanya, pedoman wawancara yang digunakan hanya berupa garis-garis besar permasalahan yang akan ditanyakan. Wawancara tidak terstruktur atau terbuka sering digunakan dalam penelitian pendahuluan atau malahan untuk penelitian yang lebih mendalam tentang responden. Untuk mendapatkan gambaran permasalahan yang lebih lengkap, maka peneliti perlu melakukan wawancara kepada pihak-pihak yang mewakili berbagai tingkatan yang ada dalam objek.

Berdasarkan uraian di atas, peneliti menggunakan wawancara tidak terstruktur dan yang akan dijadikan responden adalah guru-guru mata pelajaran fisika MTs Madani Alauddin Pao-Pao Kabupaten Gowa.

\section{HASIL PENELITIAN DAN PEMBAHASAN}

Berdasarkan analisis deskriptif dan statistik inferensial yang dilakukan, maka pada pembahasan ini dapat kemukakan sebagai berikut:

a. Hasil statistik deskriptif

Berdasarkan hasil penelitian yang telah dilakukan dengan metode pengumpulan data melalui instrument angket, disajikan hasil statistik deskriptif untuk memberikan gambaran tentang kebutuhan penghargaan (esteem needs) siswa MTs Madani Alauddin Pao-pao berada pada kategori sedang dengan skor rata-rata 70,48, yang diperoleh oleh 39 siswa, jika dinyatakan dalam persen diperoleh $98 \%$.

Berdasarkan hasil penelitian yang telah dilakukan dengan metode pengumpulan data melalui instrument angket, disajikan hasil statistik deskriptif untuk

\footnotetext{
${ }^{7}$ Sugiyono, Statistik untuk penelitian (Bandung: Alfabeta, 2010), hlm. 134-135. hlm. 317

${ }^{8}$ Sugiyono, Metodologi Penelitian Kuantitatif, Kualitatif, dan R\& D (Bandung: Alfabeta, 2012),

${ }^{9}$ Ibid., hlm. 197.
} 
memberikan gambaran tentang kompetisi dalam belajar (learning of competition) siswa MTs Madani Alauddin Pao-Pao Kabupaten Gowa berada pada kategori sedang dengan skor rata-rata 60,45, yang diperoleh oleh 39 siswa, jika dinyatakan dalam persen diperoleh $98 \%$.

Berdasarkan hasil penelitian yang telah dilakukan dengan metode pengumpulan data melalui instrument angket, disajikan hasil statistik deskriptif untuk memberikan gambaran tentang kreativitas belajar siswa MTs Madani Alauddin Pao-Pao Kabupaten Gowa berada pada kategori sedang dengan skor rata-rata $\mathbf{8 4 , 8 5}$, yang diperoleh oleh 39 siswa, jika dinyatakan dalam persen diperoleh $98 \%$.

b. Hasil statistik Inferensial

Berdasarkan hasil pengujian statistik inferensial yang telah di uraikan, maka dapat dikemukakan bahwa kebutuhan penghargaan (esteem needs) dan kompetisi dalam belajar (learning of competition) dengan kreativitas belajar fisika siswa MTs Madani Alauddin Pao-Pao Kabupaten Gowa memiliki hubungan yang signifikan.

Hasil ini didukung berbagai teori bahwa faktor penting dalam meningkatkan kreativitas belajar siswa adalah peran guru. Banyak sekali hal yang dapat dilakukan guru di sekolah untuk merangsang dan meningkatkan daya pikir siswa, sikap dan prilaku kreatif siswa. Di antaranya dengan pemberian penghargaan kepada siswa yang berprestasi. Dalam kegiatan belajar mengajar, penghargaan mempunyai arti penting. Tingkah laku dan keberhasilan belajar siswa siswi diberi penghargaan dalam bentuk pujian, senyuman dan sebagainya. Dengan adanya penghargaan dari guru, maka siswa akan terus belajar secara maksimal untuk mendapatkan penghargaan tersebut. Bahkan siswa tersebut akan bersaing atau melakukan kompetisi dengan siswa siswi yang lain. Adanya persaingan atau kompetisi siswa dalam proses belajar merupakan salah satu faktor yang kuat dalam memotivasi siswa dalam belajar.

Dan dari hasil analisis pengujian hipotesis dengan menggunakan korelasi produk moment dapat dilihat bahwa hubungan antara kebutuhan penghargaan $\left(\mathrm{X}_{1}\right)$ dengan kreativitas belajar fisika siswa (Y) mendapatkan skor 0,99 yang memiliki tingkat hubungan sangat kuat. Dan hubungan antara kompetisi dalam belajar fisika $\left(\mathrm{X}_{2}\right)$ dengan kreativitas belajar fisika siswa (Y) yang mendapatkan skor 0,99 yang artinya memiliki tingkat hubungan yang sangat kuat pula. Begitu pula dengan hubungan kebutuhan penghargaan $\left(\mathrm{X}_{1}\right)$ dengan kompetisi dalam belajar fisika $\left(\mathrm{X}_{2}\right)$ yang mendapatkan skor 0,99 yang artinya memiliki tingkat hubungan yang sangat kuat. Maka dapat disimpulkan bahwa kebutuhan penghargaan $\left(\mathrm{X}_{1}\right)$ dan kompetisi dalam belajar $\left(\mathrm{X}_{2}\right)$ sangat kuat hubungannya dengan kreativitas belajar siswa itu sendiri,

Data ini juga semakin diperkuat oleh hasil pengujian signifikannya yang memperlihatkan bahwa nilai $\mathrm{F}$ hitung yang diperoleh lebih besar dari $\mathrm{F}$ tabel, atau $1144,3 \geq 3,23$ maka $\mathrm{H}_{\mathrm{a}}$ diterima dan $\mathrm{H}_{0}$ ditolak, artinya terdapat hubungan yang 
signifikan antara kebutuhan penghargaan (esteem needs) dan kompetisi dalam belajar (learning of competition) dengan kreativitas belajar fisika siswa MTs Madani Alauddin Pao-Pao Kabupaten Gowa sehingga dapat dinyatakan bahwa korelasi ganda tersebut signifikan dan dapat diberlakukan ke populasi.

\section{PENUTUP}

Berdasarkan hasil paparan penelitian dan pembahasan di atas dan dikemukakan kesimpulan sebagai berikut: Pertama, kebutuhan penghargaan menyangkut aspek-aspek menghargai diri sendiri dan penghargaan dari orang lain. Dengan demikian, diharapkan kepada para guru untuk selalu memperhatikan dan menghargai pendapat siswanya pada saat proses pembelajaran berlangsung. Kedua, Di usia sekolah menengah, dalam hal ini siswa SMP mulai memasuki dunia baru yang berbeda dengan pengalaman di Sekolah Dasar (SD) dan mengalami banyak hal baru, sehingga perlu melakukan berbagai penyesuaian.

Tantangan globalisasi serta perubahan-perubahan lain yang terjadi di sekolah, menjadi beberapa sumber masalah bagi siswa, karena jika siswa tidak dapat menyesuaikan diri dengan perubahan-perubahan yang terjadi, maka siswa akan menjadi kurang percaya diri jika harus berkompetisi dengan teman-teman sekelasnya. Oleh karena itu, dibutuhkan bimbingan dan motivasi dari seorang guru agar siswa semangat dalam belajar. Ketiga, Para guru diharapkan bisa meningkatkan mutu kinerjanya dan meningkatkan kompetensinya sesuai dengan kemampuan yang dimiliki. sehingga dalam pembelajaran akan berjalan lebih baik di masa mendatang.

\section{DAFTAR PUSTAKA}

Ali, Muhammad dan Asrosi. 2006. Psikologi Remaja dan Perkembangan Peserta Didik. Jakarta: Bumi aksara

Arikunto, Suharsimi. 2010. Manejemen Penelitian; Jakarta: Rineka Cipta.

Bernard, Poduska. 2000. 4 teori kepribadian (Eksistensialis Behavioris, Psikoanalitik, Aktualisasi Diri). Jakarta: Restu Agung.

Departemen Agama RI. 2005. Al-Qur'an dan Terjemahannya.

Djamarah, Syaiful Bahri. 2011. Psikologi. Jakarta: Rineka Cipta.

Hamalik, Oemar. 2001. Perencanaan Pengajaran Berdasarkan pendekatan Sistem. Bandung: Bumi Aksara.

2009. Psikologi Belajar dan Mengajar, Bandung: Sinar Baru Algesindo. 
http://eprints.undip.ac.id/11107/1/JURNALKU.pdf (diakses 22 April 2013).

Jurnal. Admin. http://journal.unair.ac.id/filerPDF/artikel\%201-13-1.pdf (diakses 12 oktober 2012).

Monks. F. J. dkk. 1999. Psikologi Perkembangan Pengantar dalam Berbagai Bagiannya. Yogyakarta: Gadjah Mada University Press.

Muhamad. 2008. Metodologi Penelitian Ekonomi Islam. Jakarta: Raja Grafindo Persada.

Munandar Utami. 2009. Pengembangan Kreativitas Anak Berbakat, Jakarta: Rineka Cipta.

Mustaqim dan Wahib. 1991. Psikologi Pendidikan. Jakarta: Rineka Cipta.

Nurjan, Syarifan, dkk. 2009. Psikologi Belajar. Surabaya: Amanah Pustaka.

Purnasamari, Ayu. 2007. Hubungan antara Kecerdasan Interpersonal Remaja dengan Efektivitas Komunikasi pada Orangtua. Malang: UIN Malang.

Rahmat. J. 2000. Psikologi Komunikasi. Bandung: Remaja Rosdakarya.

Ridwan. 2008. Belajar Lebih Mudah untuk Guru, Karyawan dan Peneliti Pemula. Bandung: Alfabeta.

Sardiman. 2001. Interaksi dan Motivasi Belajar Mengajar. Jakarta: Raja Grafindo Persada.

Slameto. 2003. Belajar dan Faktor-faktor Yang Mempengaruhinya. Jakarta: Rineka Cipta.

Soejono. S. 1990. Sosiologi Suatu Pengantar. Jakarta: Raja Grafindo Persada.

Sudjana, Nana. 1987. Tuntunan Penyusunan Karya Ilmiah (Makalah, Skripsi, Tesis, Disertasi). Bandung: Sinar Baru algesindo. 2009. Penelitian dan Penilaian Pendidikan. Bandung: Sinar Baru Algesindo.

Sugiyono. 2009. Metodologi Penelitian Kuantitatif, Kualitatif, dan $R$ \& D. Bandung: Alfabeta . 2010. Statistik untuk penelitian. Bandung: alfabeta. . 2011. Metode Penelitian Pendidikan. Bandung: Alfabeta. . 2012. Metodologi Penelitian Kuantitatif, Kualitatif, dan R\& D. Bandung: Alfabeta. 
Tanjung Bahdin Nur dan Ardial. 2008. Pedoman Penulisan Karya Tulis Ilmiah (Proposal, Skripsi, dan tesis) dan Memepersiapkan Diri Menjadi Penulis Artikel Ilmiah, Jakarta: Kencana.

Wirawan Sarlito. 1982. Pengantar Umum Psikologi. Jakarta: Bulan Bintang. 